\title{
MATERNAL STATUS, NUTRITIONAL STATUS, AND PSYCHOSOCIAL STIMULATION AS DETERMINANT FACTORS OF COGNITIVE DEVELOPMENT AMONG CHILDREN UNDER FIVE
}

\author{
Rachma Purwanti $^{1}$, Ani Margawati ${ }^{1}$, Bagoes Widjanarko ${ }^{2}$ \\ ${ }^{1}$ Nutrition Department, Faculty of Medicine, Universitas Diponegoro, \\ Jl. Prof. Soedarto, SH, Kampus Undip Tembalang, Semarang, Indonesia 50275 \\ ${ }^{2}$ Faculty of Public Health, Universitas Diponegoro \\ Jl. Prof. Soedarto, SH, Kampus Undip Tembalang, Semarang, Indonesia 50275 \\ rachmapurwanti@fk.undip.ac.id
}

\begin{abstract}
Early childhood development (ECD) has long-life effects on an individual, that were essential for human capital accumulation and contribute to economic growth. This study aimed to analyzed factor that contributed to cognitive development. This study used cross sectional design by purposive sampling technique. Sample study were 61 early childhood 4-5 years old. Data collected by conducting interviews, observation, and anthropometric measurements. Nutritional status data were collected by using anthropometry, psychosocial stimulation was collected by using ECHOME inventory instrument, and cognitive development was measured using instrument developed by the Department of National Education of Indonesia. Data analysis includes descriptive test, correlation, and regression. There were $23 \%$ of children with underweight, $78.7 \%$ children get high risk of psychosocial stimulation, and $57.6 \%$ have a good cognitive development. The correlation test showed that there were significant association between the psychosocial stimulation and nutritional status to the cognitive development. Regression model also showed that cognitive development was predicted by maternal status (working mothers/housewife), nutritional status, and psychosocial stimulation.
\end{abstract}

Keywords: nutritional status; maternal status; psychosocial stimulation; cognitive development; children under five

\begin{abstract}
Abstrak
Perkembangan pada masa balita akan berdampak panjang pada seorang individu berkaitan dengan kualitas sumber daya manusia dan kontribusi terhadap perkembangan ekonomi di masa yang akan datang. Penelitian ini bertujuan untuk menganalisis faktor determinan perkembangan kognitif pada balita. Penelitian ini menggunakan desain cross sectional dengan teknik pengambilan subjek secara purposif. Jumlah subjek dalam penelitian ini sebanyak 61 balita dengan usia 4-5 tahun. Data dikumpulkan melalui wawancara terstruktur, pengamatan, dan pengukuran antropometri. Data status gizi dikumpulkan dengan pengukuran antropometri, data stimulasi psikososial dikumpulkan dengan instrumen EC-HOME inventory, dan data perkembangan kognitif balita dikumpulkan dengan instrumen dari Departemen Pendidikan Nasional Indonesia. Analisis data meliputi uji univariat, bivariat, dan multivariat. Terdapat $23 \%$ balita yang mengalami gizi kurang, sebanyak $78,7 \%$ balita berisiko tinggi kekurangan stimulasi psikososial, dan $57,6 \%$ balita memiliki perkembangan kognitif yang baik menurut usianya. Ada hubungan antara status gizi, dan stimulasi psikososial dengan perkembangan kognitif balita. Model regresi juga menunjukkan bahwa perkembangan kognitif yang baik pada balita diprediksi oleh status ibu (bekerja/ibu rumah tangga), status gizi, dan stimulasi psikososial.
\end{abstract}

Kata kunci: status gizi; status ibu; stimulasi psikososial; perkembangan kognitif; anak balita

\section{INTRODUCTION}

The early years of life were a critical period of a child's development. It's will have a long impact on an individual. This was related to the quality of human resources and contribution to economic development in the future (S. Grantham-McGregor et al., 2007). Cognitive 
development quality develops rapidly during early childhood and will determine various aspects of life in the future such as intellectuality, achievement, productivity, and quality of life (Attanasio, 2015; Britto et al., 2017; Heckman, Moon, Pinto, Savelyev, \& Yavitz, 2010; Papalia \& Feldman, 2008)

Currently, more than 250 million under-fives years old children (early childhood) in the developing countries were known to be at risk of not achieving optimal development (Black et al, 2017). It was influenced by biological, environmental, and psychosocial factors ( $\mathrm{S}$. Grantham-McGregor et al., 2007). One of the environmental factors that determine whether or not genetic potential is nutrition (Schady, 2011). Optimal nutrition during infancy and early childhood was important to support growth and development. Poor nutritional status can reduce the body's immunity to disease, on the other hand, disease recurrence can also be harmed on nutritional status. Undernutrition which was an important determinant of maternal and child health harmed the brain and cognitive development of children (Chattopadhyay \& Saumitra, 2016).

A meta-analysis study revealed that early stimulation and nutrition interventions given to low - middle-income countries showed an impact on the cognitive development of children aged 2 years (Aboud \& Yousafzai, 2015). Stimulation and nutrition had a synergistic impact on child development. Stimulation was consistently associated with child development, whereas nutrition had an impact on nutritional status and linear growth of children, then it can also have an impact on children's development (Aboud \& Yousafzai, 2015; Grantham-McGregor, Fernald, Kagawa, \& Walker, 2014).

Psychosocial stimulation has become a part of early intervention that's beneficial for child development (Padmonodewo, 2001).

Psychosocial stimulation was a combination of providing physical stimulation and emotional stimulation by caregivers which creates attachment to the child and helps facilitate emotional, social, language, psychomotor, and cognitive development in children (WHO, 2006). Psychosocial stimulation is the quality of the care environment for pre-school age children provided by parents and families including stimulation for learning, improving academic skills, language, providing a supportive physical environment, modeling, warmth and acceptance, variations in parenting, and punishment. Psychosocial stimulation was measured by the Early Childhood Home Observation for Measurement of the Environment Inventory (EC-HOME inventory) (Caldwell \& Bradley, 2003).

According to UNICEF-WHO in 2016, it is known that there were 52 million malnourished children in the world and more than 17 million children experience severe malnutrition (UNICEF, WHO, \& World Bank, 2018). To date, only a few studies have discussed the link between health, nutrition, early stimulation, and child protection to improve children's health and development in developing countries (Black \& Dewey, 2014; Grantham-McGregor et al., 2014; Komro, Tobler, Delisle, Mara, \& Wagenaar, 2013). Likewise, in Indonesia, there has not been much research linking these aspects although malnutrition still became a problem.

The proportion of wasting and underweight as a result of the 2013 Basic Health Research was $19.6 \%$, consisting of $5.7 \%$ wasting and $13.9 \%$ underweight. The proportion of wasting and underweight in under five-years old children based on Basic Health Research data in 2018 is $17.7 \%$, with $3.8 \%$ wasting and $13.8 \%$ underweight. If the two survey results compared, it was known that the decline in the proportion from 2013-2018 is not quite 
significant, especially in a problem of the proportion of malnutrition (Badan Penelitian dan Pengembangan Kesehatan, 2013, 2018).

Previous research on the relationship between nutritional status and cognitive development examined cognitive aspects, namely the concept of forms and patterns, acceptance and language, non-verbal IQ, short-term memory, and intellectual intelligence (Eilander et al., 2010; Salimar, Hastuti, \& Latifah, 2011). Cognitive development in this study included aspects of general knowledge and science, the concept of shapes, colors, patterns, numbers, number symbols, and letters. This cognitive aspect was important to research because based on the Regulation of the Minister of National Education Number 58 of 2009, these were aspects of cognitive development that must be achieved in 4-5 years old pre-school children (Kemendiknas, 2009). The stimulation studied in this study was psychosocial stimulation by mothers to children using the EC-HOME inventory instrument (Caldwell \& Bradley, 2003). This study also pays attention to maternal factors that can influence child development, such as maternal education and maternal status (working/housewife).

This study generally aims to describe the cognitive development of early childhood (4 - 5 years old) and to analyze the determinants/ predictors. The specific objectives were: 1) to identify the characteristics of children under five and their families, 2) to describe maternal factors (education and status of mothers (working or housewives), nutritional status, psychosocial stimulation, and children under five cognitive development, 3) to analyze the relationship between maternal education, maternal status, nutritional status, and psychosocial stimulation with toddler cognitive development, and 4) to analyze determinant factors of toddler cognitive development.

\section{METHODS}

This study used a cross-sectional design with a purposive sampling technique. Sample study were 61 children aged 4-5 years. Inclusion criteria such as still have a biological mother and live together, live in the Bugangan Public Health Center area, Semarang City until the end of the study. The exclusion criteria were children under five with over nutritional status (index weight/age $>2 S D$ ), incomplete data, and subjects unable to follow the study until the end. Data were collected by using interviews, observations, and anthropometric measurements of toddlers.

Cognitive development was a person's ability to think included the ability to remember, reason, assess, imagine, and speak (Papalia \& Feldman, 2008). Cognitive development was assessed by a child development instrument developed by the Ministry of National Education (Kemendiknas, 2009) with a low cognitive development category if the score was $<60$ and good if the score was $\geq 60$, the nutritional status of under-fives years old children was measured by the anthropometric index weight for ages (W/A) with underweight category if $\mathrm{z}$ score < $2 S D$ and normal nutritional status if $z$ score between $-2 S D$ to $2 S D$ (Direktorat Jenderal Bina Gizi dan Kesehatan Ibu dan Anak, 2011), and psychosocial stimulation in this study is the stimulation given by mothers

to their children using the EC-HOME inventory for children aged 3-6 years developed by Caldwell and Bradley. The psychosocial stimulation instrument (EC-HOME inventory) consists of 55 question items covering 8 aspects, namely: 1) learning stimulation, 2) language stimulation, 3) academic stimulation, 4) pride and affection, 5) warmth and acceptance (positive punishment), 6) modeling, 7) stimulation variate and 8) physical environment organization. Psychosocial stimulation was classified at risk if the 
Psychosocial Stimulation as Determinant Factors of Cognitive Development Among Children Under Five stimulation score was $<40$ and classified as not risk if the stimulation score was $\geq 40$ (Caldwell \& Bradley, 2003).

Learning stimulation includes providing facilities such as puzzles, learning colors with cards, and picture books. Language stimulation, academic stimulation, pride, and affection and acceptance emphasize the active role of the caregiver to provide cognitive development stimulation. Modeling included how well the caregivers became role models for their children. Variate stimulation was a combination of facilities and the active role of caregivers to improve children's cognitive development. The physical environment includes aspects of the house such as ventilation, lighting, cleanliness, and home density (Caldwell \& Bradley, 2003).

Data analysis includes descriptive test, correlation, and regression. The descriptive test used was frequency distribution test, the correlation test used was chi-square, and the multivariate test used was multiple logistic regression. Descriptive tests were carried out on the variables of the subject's gender, maternal education, maternal status, per capita income, nutritional status of children under five, psychosocial stimulation of children under five, and cognitive development of children. A correlation test with chi-square was conducted to examine the relationship between variables of subject gender, maternal education, maternal status, children nutritional status,

and psychosocial stimulation, with early childhood cognitive development. A multivariate test with multiple logistic regression was carried out to predict the effect of variables altogether (variables that had $p<$ .05 in bivariate correlation tests, namely maternal education, maternal status, nutritional status, and psychosocial stimulation) on early childhood cognitive development.

\section{RESULTS AND DISCUSSIONS}

The distribution of subjects according to gender was evenly distributed (Male: $49.2 \%$ and Female: $50.8 \%$ ). Most of the mothers aged 2035 years $(68.9 \%)$. The distribution of maternal education is quite diverse and the highest percentage (more than half of the number of mothers) had a high school education (62.3\%). Only $4.9 \%$ of mothers had completed school to tertiary education. Although the average maternal education was still low, all mothers in this study were able to read and write. Based on maternal status (working/ housewife), it was known that the percentage of housewives is $44.3 \%$. The average per capita income is IDR 416,273.00.

The nutritional status of children under five was measured by the weight for age index showed that $77 \%$ of children under five were normal nutritional status and $23 \%$ of children were malnourished (z score $<-2 S D$ ). Based on the EC-HOME inventory questionnaire, it was known that most of the children under five are at high risk, means that they are not getting enough psychosocial stimulation (80.3\%). Among the 8 aspects of psychosocial stimulation, more than half of the subjects received intermediate scores (average) for learning stimulation, pride and affection, academic stimulation, modeling, and variations in stimulation. Language stimulation and acceptance showed high scores, while scores for stimulation of learning, the physical environment, and parenting variations in most subjects scored low.

The results showed that $57.4 \%$ of children had a good level of cognitive development, while the rest had low cognitive development $(<60 \%$ according to their age range). In general, cognitive development aspects in children were categorized as good in each aspect, including recognizing objects based on function, recognizing causality symptoms related to 
themselves, and creating something according to their ideas. The ability to classify objects based on shape, color, or size, recognize patterns, and sort objects based on color or size series are also good. Likewise understanding the concepts of many and few and counting many objects 1-10. Aspects that still less developed were how to use objects as a game symbolically, recognizing the symbols of numbers and letters.

The period of 3-5 years old children was a period of accelerated maturation and function of the prefrontal cortex, the part of the brain that supports the development or improvement of cognitive function, regulating emotions, attention, and behavior, as well as reasoning skills that can change supported by environment and experience. These skills were important for children's readiness for school and crucial for the success of children moving from pre-school years (Obradovic, XA, \& WT, 2012). This study was conducted on 4-5 years old children, who were in the range of accelerated maturation and function of the prefrontal cortex. Table 1 shows that the variables related to cognitive development in 4-5 years old children were nutritional status and psychosocial stimulation.

Table 1 was a cross-tabulation of the variables of gender, maternal education, maternal status, per capita income, psychosocial stimulation, and nutritional status on children's cognitive development. Based on table 1, it was known that the variables that were significantly related to cognitive development were psychosocial stimulation and nutritional status. There was no relationship between gender, maternal education, and maternal status with early childhood cognitive development.

Table 1.

Cross-Tabulation and Odds Ratio of Children's Cognitive Development Based on Predictors

\begin{tabular}{|c|c|c|c|c|c|c|}
\hline \multirow{3}{*}{ Variables } & \multicolumn{6}{|c|}{ Cognitive Development Scores } \\
\hline & \multicolumn{2}{|c|}{ high } & \multicolumn{2}{|c|}{ low } & \multirow[t]{2}{*}{$\mathrm{OR}$} & \multirow[t]{2}{*}{$p$} \\
\hline & $n$ & $\%$ & $n$ & $\%$ & & \\
\hline \multicolumn{7}{|l|}{ 1. Gender } \\
\hline Male & 18 & 60 & 12 & 40 & - & .684 \\
\hline Female & 17 & 54.8 & 14 & 45.2 & & \\
\hline \multicolumn{7}{|l|}{ 2. Maternal education } \\
\hline Primary School & 0 & 0 & 2 & 100 & - & .056 \\
\hline Junior High School & 7 & 41.2 & 10 & 58.8 & & \\
\hline Senior High School & 25 & 65.8 & 13 & 34.2 & & \\
\hline Higher Education & 3 & 100 & 0 & 0 & & \\
\hline \multicolumn{7}{|l|}{ 3. Maternal status } \\
\hline Working mothers & 23 & 67.6 & 11 & 32.4 & - & .068 \\
\hline Housewife & 12 & 44.4 & 15 & 55.6 & & \\
\hline \multicolumn{7}{|l|}{ 4. Psychosocial Stimulation } \\
\hline At risk $($ score $<40)$ & 24 & 49 & 25 & 51 & 11.5 & $.019 *$ \\
\hline Not risk $($ score $\geq 40)$ & 11 & 91.7 & 1 & 8.3 & & \\
\hline \multicolumn{7}{|l|}{ 5. Children nutritional status } \\
\hline Underweight & 3 & 21.4 & 11 & 78.6 & 7.8 & $.005 *$ \\
\hline Normal & 32 & 68.1 & 15 & 31.9 & & \\
\hline
\end{tabular}

Note. ${ }^{*} p<.05$.

The variables included in the multivariate analysis in this study were maternal education, maternal status, children nutritional status, and psychosocial stimulation. The results of the 
multivariate analysis were presented in table 2. Factors that became predictors of early childhood cognitive development in this study were maternal status, children nutritional status, and psychosocial stimulation as indicated by logistic regression equations, namely:

cognitive development $(\mathrm{z})=-2.144-1.824$ maternal status +1.638 children nutritional status +2.954 psychosocial stimulation.

Based on this equation, it can be calculated that the probability of cognitive development is lower if the mother was housewife, the children was underweight, and other conditions with the logistic function:

$\mathrm{f}(\mathrm{z})=1 /(1+\mathrm{e}-(-2.144-1.824$ maternal status +1.638 children nutritional status +2.954 psychosocial stimulation))

These three factors can predict $41.1 \%$ of the cognitive development of children under five. The quality of the equations obtained is seen in terms of discrimination and calibration. The quality of the discrimination parameters seen from the ROC value was .780, which means that the predictive quality of the equation is moderate, while the quality of the calibration

parameters seen from the $p$-value on the Hosmer and Lemeshow Test is .894. This means that the regression equation obtained has good calibration (Dahlan, 2019).

The results of the bivariate analysis did not show any relationship between maternal status and cognitive development, but the results of the multivariate analysis showed that maternal status was one of the factors that participated in predicting cognitive development. Maternal status became a protective factor from low cognitive development $(\mathrm{OR}=.161)$, while the children's nutritional status and psychosocial stimulation were risk factors for low cognitive development $(\mathrm{OR}=5.144$ and $\mathrm{OR}=19.174)$. Children with at-risk psychosocial stimulation will decrease on cognitive development by 19.174 times greater than those with psychosocial stimulation (not at sufficient risk). Meanwhile, children with underweight have a 5.144 times greater risk of experiencing low cognitive development than children with normal nutritional status.

Table 2.

Final Regression Model of Cognitive Development Predictors

\begin{tabular}{lccccc}
\hline Variable & Coefficients & $S E$ & $p$ & $\operatorname{Exp}(\mathrm{B})$ & $95 \%$ CI \\
\hline Maternal status & -1.824 & .707 & $.010^{*}$ & .161 & {$[.040, .645]$} \\
Psychosocial stimulation & 2.954 & 1.199 & $.014 *$ & 19.174 & {$[1.830,200.925]$} \\
Children nutritional status & 1.638 & .788 & $.038^{*}$ & 5.144 & {$[1.09,24.126]$} \\
\hline
\end{tabular}

Nagelkerke $R^{2}=.411$

Note. $\mathrm{ROC}$ value $=.780 .{ }^{*} p<.05$.

Maternal status as a protective factor means that the status of a working mothers protects the cognitive development of children. Cognitive development can still be optimized with good parenting, psychosocial stimulation, and good nutritional status. Maternal status as a protective factor for cognitive development was based on the results in table 2, which was in line with the results of the analysis in table 1 that better cognitive development was more in children with working mothers $(67.6 \%)$ than the other

(44.4\%). This can be related to the role of mothers in their care and quality of care.

Early childhood is a crucial mass for cognitive, affective, and psychomotor development so that the role of mothers is needed. Working mothers were healthier and less depressed or sad than mothers who do not work so that they can carry out their work roles and in their families well. Besides, maternal status (working / not) does not have an impact on children's cognitive 
development because every mother will always try to give her best to support the development of her child. Although in infants (children aged 0-12 months), working mothers status can gave a negative effect on the emotional development and attachment of children to their parents (Almani, Abro, \& Mugheri, 2012).

The allocation of a mother's time for caring also does not fully impact on children's cognitive development. In fact, mothers with higher education and better quality of care would give better cognitive development (Brilli, 2015). Other study report that maternal time investments play a small but significant role in child cognitive development (Felfe \& Hsin, 2012). When a mother was able to be balance between working and taking care of her family and was satisfied with her husband's help, the child's growth and development will be optimal. When the mother can balance work and family but there was no support from the family, or when there was support from the family but the mother tends to ignore the child in care, the child's development will be less than optimal (Handayani \& Munawar, 2015).

Other study reports that the relationship between maternal employment and children's outcomes is not unidimensional. For example, children of self-employed mothers are not disadvantaged compared to those with stay-athome mothers, but maternal employment in wage work outside the home is negatively associated with cognitive skills in children. However, this negative association is reversed at higher levels of maternal education, suggesting greater access to resources and flexibility associated with better jobs mitigate the negative aspects of maternal employment posed by time constraints (Vikram, Chen, \& Desai, 2018).

This study found that the influence of psychosocial stimulation on cognitive development. Good stimulation support will improve child cognitive abilities. Children who get directed and regular stimulation will develop faster than the others who don't get stimulation (Soetjiningsih, 2012). Most of the psychosocial stimulation in this study was included as risky (not enough stimulation). Psychosocial stimulation that was still lacking based on the results of this study is the stimulation of learning (especially about geometric shapes), variations in parenting (taking children when traveling, taking children to museums, and getting used to eating together with all family members), and creating a play environment around the house. safe for children.

According to Piaget's developmental stages, ages 4-7 years were an intuitive developmental stage. Children at this stage were increasingly able to live in society, but they were not yet able to think mutually. He only pays attention to and imitates adult behavior (Papalia \& Feldman, 2008). Psychosocial stimulation was indispensable for achieving optimal development at this intuitive stage. Psychosocial stimulation was related to children's cognitive development (table 1). Low cognitive development occurs in under-five children with risky psychosocial stimulation (51\%). Only $8.3 \%$ of children with sufficient psychosocial stimulation had low cognitive development. There was a significant difference between children who receive good psychosocial stimulation and less psychosocial stimulation.

Inadequate cognitive stimulation can decrease child developmental potential (Engle et al., 2007). On the other hands, children who get responsive stimulation can have better cognitive, language, and motoric development than children who get less stimulation (Yousafzai et al., 2016). Other study report that both maternal and paternal stimulation significantly effects on children's longer-term cognitive and socioemotional development. 
Greater indirect effects were found through maternal than paternal stimulation (Jeong et al., 2019).

Psychosocial stimulation given to malnourished children can also improve their cognitive development (Nahar et al., 2009). Likewise, programs to improve the quality of care can have a significant impact on improving health, cognitive development, and social-emotional (Bernal, 2015). Other studies has reported that psychosocial stimulation and maternal workload affect children's cognitive development (Salimar et al., 2011).

This study shows that underweight children were at more risk of experiencing less cognitive development (78.6\%) than children with normal nutritional status (31.9\%). This shows that nutritional status plays an important role in early childhood cognitive development. Nutritional status was also a predictor of cognitive development, along with maternal status and psychosocial stimulation. Normal nutritional status, maternal status, and good psychosocial stimulation can improve cognitive development. Also, these three factors contribute $41.1 \%$ to the children cognitive development.

Malnutrition status can result in growth and development disorders, causing a reduction in the number of brain cells, and an impact on changes in brain structure and function (Chattopadhyay \& Saumitra, 2016; Fuglestad, Rao, \& Georgieff, 2006). Inadequate nutritional status can also reduce the body's immunity to disease (Chattopadhyay \& Saumitra, 2016) so that the body was susceptible to disease, also cannot reach optimal development. Malnutrition status was a major problem so that children are more prone to developmental disorders (De \& Chattopadhyay, 2019).

The results of this study were in line with the results of longitudinal studies conducted in previous developing countries that good nutrition is related to cognitive development (Eilander et al., 2010; Galván, Uauy, Corvalán, López-Rodríguez, \& Kain, 2013; Sandjaja et al., 2013). Research in China also shows that micronutrient deficiency and lack of parental stimulation (telling stories, teaching reading, singing, and playing together) have an impact on children's development (Wang et al., 2019). Intake of nutrients such as energy, fat, protein, and zinc has also been reported to be associated with the children's cognitive development (Purwanti, 2017). Adequacy of nutrition and its effect on nutritional status, as well as the ability of parents to create a supportive living environment and provide good stimulation, were predictors of cognitive development in a child.

\section{CONCLUSION}

Children under five cognitive development was predicted by maternal status, nutritional status, and psychosocial stimulation. These factors can be pursued to achieve optimal cognitive development.

\section{REFERENCES}

Aboud, F. E., \& Yousafzai, A. K. (2015). Global Health and Development in Early Childhood. Annual Review of Psychology, 66, 433-457.

Almani, A. S., Abro, A., \& Mugheri, R. A. (2012). Study of the Effects of Working Mothers on the Development of Children in Pakistan. International Journal of Humanities and Social Science, 2(11), 164171.

Attanasio, O. P. (2015). The determinants of human capital formation during the early years of life: theory, measurement, and policies. Journal Ofthe European Economic Association, 13(December), 949-997. https://doi.org/10.1111/jeea.12159 
Badan Penelitian dan Pengembangan Kesehatan. (2013). Riset Kesehatan Dasar (RISKESDAS) 2013. Laporan Nasional 2013, 1-384. https://doi.org/1 Desember 2013

Badan Penelitian dan Pengembangan Kesehatan. (2018). Riset Kesehatan Dasar (Riskesdas) 2018.

Bernal, R. (2015). Economics of Education Review The impact of a vocational education program for childcare providers on children' s well-being. Economics of Education Review, 48, 165-183. https://doi.org/10.1016/j.econedurev.2015. 07.003

Black, M. M., \& Dewey, K. G. (2014). Promoting equity through integrated early child development and nutrition interventions. Ann. N.Y. Acad. Sci, (1308), 1-10. https://doi.org/10.1111/nyas.12351

Black, M. M., Walker, S. P., Fernald, L. C., Andersen, C. T., DiGirolamo, A. M., Lu, C., .. \& Devercelli, A. E. (2017). Early childhood development coming of age: science through the life course. The Lancet, 389(10064), 77-90.

Brilli, Y. (2015). Mother's Time Allocation, Child Care and Child Cognitive Development Mother's Time Allocation, Child Care and Child Cognitive Development (No. 320116) (Vol. 29).

Britto, P. R., Lye, S. J., Proulx, K., Yousafzai, A. K., Matthews, S. G., Vaivada, T., ... Leckman, J. F. (2017). Advancing Early Childhood Development: from Science to Scale 2 Nurturing care: promoting early childhood development. Lancet, 389. https://doi.org/10.1016/S01406736(16)31390-3

Caldwell, B. M., \& Bradley, R. H. (2003).
HOME inventory administration manual standard versions (3rd ed.). Arkansas University Press.

Chattopadhyay, N., \& Saumitra, M. (2016). Developmental Outcome in Children with Malnutrition. J. Nepal Paediatr. Soc., 36(2), 170-177.

Dahlan, S. (2019). Statistik untuk Kedokteran dan Kesehatan: Deskriptif, Bivariat, dan Multivariat (Edisi 6, Cetakan Kedelapan). Jakarta: Epidemiologi Indonesia.

De, P., \& Chattopadhyay, N. (2019). E ff ects of malnutrition on child development: Evidence from a backward district of India, (January).

https://doi.org/10.1016/j.cegh.2019.01.014

Direktorat Jenderal Bina Gizi dan Kesehatan Ibu dan Anak. (2011). Keputusan Menteri Kesehatan Republik Indonesia No: 1995/MENKES/SK/XII/2010 tentang standar antropometri penilaian status gizi anak. Jakarta.

Eilander, A., Muthayya, S., van der Knaap, H., Srinivasan, K., Thomas, T., Kok, F. J., ... Osendarp, S. J. M. (2010). Undernutrition, fatty acid and micronutrient status in relation to cognitive performance in Indian school children: a cross-sectional study. British Journal of Nutrition, 103(07), 1056. https://doi.org/10.1017/S00071145099927 $3 \mathrm{X}$

Engle, P. L., Black, M. M., Behrman, J. R., Cabral de Mello, M., Gertler, P. J., Kapiriri, L., ... Young, M. E. (2007). Strategies to avoid the loss of developmental potential in more than 200 million children in the developing world. Lancet, 369(9557), 229242 . https://doi.org/10.1016/S01406736(07)60112-3

Felfe, C., \& Hsin, A. (2012). Maternal work 
conditions and child development. Economics of Education Review, 31(6), 1037-1057.

https://doi.org/10.1016/j.econedurev.2012. 06.008

Fuglestad, A. J., Rao, R., \& Georgieff, M. K. (2006). The role of Nutrition in cognitive development. In Nutrition and Cognitive Development (pp. 612-626).

Galván, M., Uauy, R., Corvalán, C., LópezRodríguez, G., \& Kain, J. (2013). Determinants of cognitive development of low SES children in Chile: A posttransitional country with rising childhood obesity rates. Maternal and Child Health Journal, 17(7), 1243-1251. https://doi.org/10.1007/s10995-012-1121-9

Grantham-McGregor, S., Cheung, Y. B., Cueto, S., Glewwe, P., Richter, L., \& Strupp, B. (2007). Developmental potential in the first 5 years for children in developing countries. Lancet, $\quad 369(9555)$, 60-70. https://doi.org/10.1016/S01406736(07)60032-4

Grantham-McGregor, S. M., Fernald, L. C. H., Kagawa, R. M. C., \& Walker, S. (2014). Effects of integrated child development and nutrition interventions on child development and nutritional status. Annual New York Academy of Sciences, (1308), 1132. https://doi.org/10.1111/nyas. 12284

Handayani, A., \& Munawar, M. (2015). Workfamily balance and quality of parenting in optimizing children development. Indonesian Journal of Early Childhood Education Studies, 4(1), 11-18. https://doi.org/10.15294/ijeces.v4i1.9447

Heckman, J. J., Moon, S. H., Pinto, R., Savelyev, P. A., \& Yavitz, A. (2010). The rate of return to the HighScope Perry Preschool Program. Journal of Public
Economics, $\quad 94(1-2), \quad$ 114-128. https://doi.org/10.1016/j.jpubeco.2009.11.0 01

Jeong, J., Obradović, J., Rasheed, M., McCoy, D. C., Fink, G., \& Yousafzai, A. K. (2019). Maternal and paternal stimulation: Mediators of parenting intervention effects on preschoolers' development. Journal of Applied Developmental Psychology, 60, 105-118.

https://doi.org/10.1016/j.appdev.2018.12.0

01

Kemendiknas. (2009). Salinan Peraturan Menteri Pendidikan Nasional Republik Indonesia Nomor 58 Tahun 2009 Tentang Standar Pendidikan Anak Usia Dini, 8-11.

Komro, K. A., Tobler, A. L., Delisle, A. L., Mara, R. J. O., \& Wagenaar, A. C. (2013). Beyond the clinic: improving child health through evidence-based community development. BMC Pediatrics, 13(172), 19.

Retrieved from http://www.biomedcentral.com/14712431/13/172

Nahar, B., Hamadani, J., Ahmed, T., Tofail, F., Rahman, A., Huda, S., \& GranthamMcgregor, S. (2009). psychosocial stimulation of children in hospital. European Journal of Clinical Nutrition, (63), 725-731.

Obradovic, J., XA, P., \& WT, B. (2012). Executive function and developmental neuroscience current progress and implications for early childhood education. In handbook of Early Childhood Education (pp. 324-351). New York: Guilford.

Padmonodewo, S. (2001). Program intervensi dini sebagai sarana peningkatan perkembangan anak. Jakarta: Universitas 
Indonesia.

Papalia, D., \& Feldman. (2008). Human Development (Psikologi Perkembangan) Bagian I-IV. Jakarta: Kencana.

Purwanti, R. (2017). Asupan zat gizi dan perkembangan kognitif balita di wilayah Puskesmas Bugangan Kota Semarang. Darussalam Nutrition Journal, 1(2), 1-9.

Salimar, Hastuti, D., \& Latifah, M. (2011). Hubungan Beban Kerja, Pengetahuan Ibu, dan Pola Asuh Psikososial Dengan Perkembangan Kognitif Anak Usia 2-5 Tahun Padaa Keluarga Miskin. Pgm, 34(1), 39-49.

Sandjaja, Poh, B. K., Rojroonwasinkul, N., Le Nyugen, B. K., Budiman, B., Ng, L. O., ... Parikh, P. (2013). Relationship between anthropometric indicators and cognitive performance in Southeast Asian schoolaged children. British Journal of Nutrition, $110(\mathrm{~S} 3)$, S57-S64. https://doi.org/10.1017/S00071145130020 79

Schady, N. (2011). Parents' education, mothers' vocabulary, and cognitive development in early childhood: Longitudinal evidence from Ecuador. American Journal of Public Health, 101(12), 2299-2307. https://doi.org/10.2105/AJPH.2011.300253

Soetjiningsih. (2012). Tumbuh Kembang Anak.
Jakarta: Penerbit Buku Kedokteran EGC.

UNICEF, WHO, \& World Bank. (2018). Levels and trends in child malnutrition.

Vikram, K., Chen, F., \& Desai, S. (2018). Mothers' work patterns and Children's cognitive achievement: Evidence from the India Human Development survey. Social Science Research, 72(December 2016), 207-224.

https://doi.org/10.1016/j.ssresearch.2018.0 2.003

Wang, L., Liang, W., Zhang, S., Jonsson, L., Li, M., Yu, C., ... Rozelle, S. (2019). Are infant / toddler developmental delays a problem across rural China? Journal of Comparative Economics, (5), 1-12. https://doi.org/10.1016/j.jce.2019.02.003

WHO. (2006). Mental Health and Psychosocial Well - Being among Children in Severe Food Shortage Situations.

Yousafzai, A. K., Obradović, J., Rasheed, M. A., Rizvi, A., Portilla, X. A., Tirado-strayer, N., ... Memon, U. (2016). Eff ects of responsive stimulation and nutrition interventions on children' $\mathrm{s}$ development and growth at age 4 years in a disadvantaged population in Pakistan: a longitudinal follow-up of a cluster-randomised factorial eff ectiveness trial. Lancet Global Health, 4(August), 548-558. https://doi.org/10.1016/S2214109X(16)30100-0 